\title{
CONTRIBUTION OF AGRICULTURAL FIELD PRODUCTION TO EMISSION OF GREENHOUSE GASES (GHG)
}

\author{
UDZIAŁ PRODUKCJI ROLNEJ \\ W EMISJI GAZÓW CIEPLARNIANYCH
}

\begin{abstract}
According to global inventories the agricultural field production contributes in a significant measure to increase of concentration of greenhouse gases $\left(\mathrm{CO}_{2}, \mathrm{~N}_{2} \mathrm{O}, \mathrm{CH}_{4}\right)$ in the atmosphere, however their estimated data of emissions of soil origin differ significantly. Particularly estimates on nitrogen-oxides emissions show a great temporal and spatial variability while their formations in microbial processes are strongly influenced by biogeochemical and physical properties of the soil (eg microbial species, soil texture, soil water, $\mathrm{pH}$, redox-potential and nutrient status) and land use management through the impact of the application of natural and synthetic fertilisers, tillage, irrigation, compaction, planting and harvesting. The different monitoring systems and inventory models were developed mostly from atmospheric chemistry point of view and little comprehensive data exist on the processes related to GHG emissions and their productions in agricultural soils under ecological conditions of Central Europe. This paper presents the new results of a project aimed elaboration of an experimental system suitable for studying relationships between the production and emission of greenhouse gases and plant nutrition supply in agricultural soils under Hungarian ecological conditions. The system was based on a long-term fertilisation field experiment. Mesocosm size pot experiments were conducted with soils originating from differently treated plots. The production of $\mathrm{CO}_{2}$ and $\mathrm{N}_{2} \mathrm{O}$ was followed during the vegetation period in gas traps built in $20 \mathrm{~cm}$ depth. Undisturbed soil columns were prepared from the untreated side parcels of the field experiment and the production of $\mathrm{CO}_{2}$ and $\mathrm{N}_{2} \mathrm{O}$ was studied at 20,40 and $60 \mathrm{~cm}$ depth. A series of laboratory microcosm experiments were performed to clarify the microbial and environmental effects influencing the gas production in soils. The $\mathrm{CO}_{2}$ and $\mathrm{N}_{2} \mathrm{O}$ were determined by gas chromatography. The $\mathrm{NO}_{\mathrm{x}}$ was detected by chemiluminescence method in headspace of microcosms. In the mesocosm and soil columns experiments influence of plant nutrition methods and environmental factors was successfully clarified on seasonal dynamics and depth profile on $\mathrm{CO}_{2}$ and $\mathrm{N}_{2} \mathrm{O}$ productions. The database developed is suitable for estimating $\mathrm{CO}_{2}$ and $\mathrm{N}_{2} \mathrm{O}$ emissions from agricultural soils.
\end{abstract}

Keywords: greenhouse gases, long term field - mesocosm - soil column - microcosm experiment

\footnotetext{
${ }^{1}$ Department of Chemistry and Biochemistry, Szent István University, Páter K. u. 1., H-2100 Gödöllö, Hungary, phone +3628522073, fax +3628410804, email: heltai.gyorgy@mkk.szie.hu

${ }^{2}$ Institute of Plant Production and Soil Sciences, University of Pannonia, Festetics u. 7., H-8360 Keszthely, Hungary, phone +3683545151 , fax +3683545254 , email: hoffmann-s@ georgikon.hu

${ }^{3}$ Institute for Soil Sciences and Agricultural Chemistry, Centre for Agricultural Research, Hungarian Academy of Sciences, Hermann O. u. 15., H-1022 Budapest, Hungary, phone +36309617461, +36309617452, fax +3612122265, email: anton@ rissac.hu; szili-k@ rissac.hu

*Corresponding author: balint.agnes@mkk.szie.hu
} 


\section{Introduction}

The global and regional inventories (IPCC [1], GEIA [2], EDGAR [3]) have been recording growing tendency in concentration of greenhouse gases (GHG) in the atmosphere $[4,5]$ up to now. The emission of $\mathrm{CO}_{2}, \mathrm{~N}_{2} \mathrm{O}, \mathrm{CH}_{4}$ and $\mathrm{NO}$ of different origin is studied extensively [6-8], however their estimated results of emissions of soil origin differ greatly $[9,10]$. Particularly, estimates on nitrogen-oxides emissions show a great temporal and spatial variability while their formations in microbial processes are strongly influenced by biogeochemical and physical properties of the soil (eg microbial species, soil texture, soil water, $\mathrm{pH}$, redox-potential and nutrient status) and land use management through the impact of the application of natural and synthetic fertilisers, tillage, irrigation, compaction, planting and harvesting [11-14]. The uncertainty connected to global estimations on nitrogen-oxides emissions of soil origin is very high and they ranged in the 9.75-21 Tg N/year interval [15-17]. The different monitoring systems and inventory models were developed mostly from atmospheric chemistry point of view and little comprehensive data exist on the processes related to GHG emissions and their production in the agricultural soils under ecological conditions of Central Europe. The aim of present study was the elaboration of an experimental system suitable for studying relationships between production and emission of greenhouse gases, and plant nutrition supply in agricultural soils under Hungarian ecological conditions. The system was based on a long-term fertilisation field experiment. In mesocosm size pot experiments and undisturbed soil columns the production of $\mathrm{CO}_{2}$ and $\mathrm{N}_{2} \mathrm{O}$ gas formation was followed by gas chromatography during the vegetation period in gas traps built into the soil at different depth. Laboratory microcosm experiments were performed to clarify the microbial and environmental effects influencing the gas production in soils.

\section{Materials and methods}

\section{Experimental system}

The experimental system was developed in cooperation of research teams of the Szent István University, Faculty of Agricultural and Environmental Faculty (SZIU FAES), University of Pannonia, Faculty of Georgikon Agricultural Sciences (UP FGAS) and Institute for Soil Sciences and Agricultural Chemistry, Centre for Agricultural Research, Institute of the Hungarian Academy of Sciences (ISSAC CAR HAS). All investigations were based on the long-term organic-mineral fertiliser experiment named "Comparison of the effect of organic and mineral fertilisers" and set up at the experimental field of the Department of Crop Production and Soil Science of UP FGAS at Keszthely $\left(46^{\circ} 40^{\prime} \mathrm{N}\right.$; $17^{\circ} 15^{\prime}$ E) in 1963. Between 2008 and 2011, mesocosm (pot), microcosm and undisturbed soil column experiments were carried out at Keszthely, Gödöllö and ISSAC CAR HAS linked to this long-term organic mineral fertiliser experiment, for quantitative estimation of $\mathrm{CO}_{2}, \mathrm{~N}_{2} \mathrm{O}$ and $\mathrm{NO}$ gas accumulation in the soil air and emitting from the soil in function of different water and nutrient (mineral and organic) supply. Mesocosm size pot experiments were conducted in the greenhouse of UP-FGAS with soils originating from differently treated plots of the field experiment. The production of $\mathrm{CO}_{2}$ and $\mathrm{N}_{2} \mathrm{O}$ was followed during the vegetation period in gas traps built in $20 \mathrm{~cm}$ depth. Undisturbed soil columns were prepared from the untreated side parcels of the field experiment and the production of $\mathrm{CO}_{2}$ 
and $\mathrm{N}_{2} \mathrm{O}$ was studied at 20,40 and $60 \mathrm{~cm}$ depth. Gas samples were taken in both experiments weekly into evacuated glass holders and they were transported to the laboratory and analysed by gas chromatograph on the sampling day. Series of laboratory microcosm experiments were performed with the incubation of soil of the field experiment to clarify the microbial and environmental effects influencing the gas production in soil. In the headspace of microcosms, the emission of $\mathrm{CO}_{2}$ and $\mathrm{N}_{2} \mathrm{O}$ was detected by gas chromatography and the $\mathrm{NO}$ was detected by chemiluminescence method.

\section{Gas analytical methods}

$\mathrm{CO}_{2}$ and $\mathrm{N}_{2} \mathrm{O}$ were measured by a gas chromatograph (HP 5890) equipped with Porapak Q column to separate carbon-dioxide, which was detected by thermal conductivity and $\mathrm{N}_{2} \mathrm{O}$, which was detected by electron capture detector. A gas-tight syringe was used to transfer $0.250 \mathrm{~cm}^{3}$ gas sample from sample holders (or from headspace of microcosms) directly into gas chromatograph. Each sample was analyzed three times using external standards and one point linear calibration. The NO concentration in microcosm headspace was measured using ANTEK 7050 chemiluminescent analyser according to operating manual.

\section{Field scale and mesocosm experiment}

In 1963 a long-term organic-mineral fertiliser experiment was set up on Ramann type brown forest soil (Eutric Cambisol) at Keszthely (46 $47^{\prime} \mathrm{N}, 17^{\circ} 15^{\prime} \mathrm{E}$; Hungary) with two crop rotations ("A" and "B" both consisting of three crops: potato, maize and wheat) and different doses of FYM or equivalent NPK fertiliser and combined treatments of NPK fertiliser and FYM or straw manuring. Only rotation "B" contained straw manuring. The trials were set up on plots of $98 \mathrm{~m}^{2}$ in randomized block design, in four replications. Mean annual temperature and precipitation (in years 1951-2000) were $10.4^{\circ} \mathrm{C}$ and $654 \mathrm{~mm}$, respectively [18]. For the present study, ten of the treatments have been selected from the two rotations (Table 1). The original fertility of this neutral sandy loam was poor in organic matter and phosphorus, medium in potassium content.

Table 1

Selected treatments of the long-term experiment

\begin{tabular}{|c|c|c|c|c|}
\hline $\begin{array}{c}\text { Treatment } \\
\text { no. }\end{array}$ & $\begin{array}{c}\text { Organic } \\
\text { amendments }\end{array}$ & Mineral fertiliser & $\begin{array}{c}\text { Total } \mathbf{N}, \mathbf{P}_{\mathbf{2}} \mathbf{O}_{\mathbf{5}}, \mathbf{K}_{\mathbf{2}} \mathbf{O} \\
{\left[\mathbf{k g} \cdot \mathbf{h a}^{\mathbf{1}} \mathbf{a}^{\mathbf{- 1}}\right]}\end{array}$ & $\begin{array}{c}\text { Codes of } \\
\text { treatments }\end{array}$ \\
\hline 1 & - & - & - & Control \\
\hline 2 & $1 \mathrm{FYM}$ & - & $44,38,49$ & $1 \mathrm{FYM}$ \\
\hline 3 & $2 \mathrm{FYM}$ & - & $88,76,98$ & $2 \mathrm{FYM}$ \\
\hline 4 & $3 \mathrm{FYM}$ & - & $132,114,147$ & $3 \mathrm{FYM}$ \\
\hline 5 & - & $1 \mathrm{eqv}$ & $44,38,49$ & 1 eqv \\
\hline 6 & - & $2 \mathrm{eqv}$ & $88,76,98$ & $2 \mathrm{eqv}$ \\
\hline 7 & - & $3 \mathrm{eqv}$ & $132,114,147$ & $3 \mathrm{eqv}$ \\
\hline 8 & $1 \mathrm{FYM}$ & $\mathrm{N}_{640} \mathrm{P}_{360} \mathrm{~K}_{660}$ & $172,110,181$ & $1 \mathrm{FYM}+\mathrm{NPK}$ \\
\hline 9 & - & $1 \mathrm{eqv}+\mathrm{N}_{640} \mathrm{P}_{360} \mathrm{~K}_{660}$ & $172,110,181$ & $1 \mathrm{eqv}+\mathrm{NPK}$ \\
\hline 10 & Straw & $1 \mathrm{eqv}+\mathrm{N}_{640} \mathrm{P}_{360} \mathrm{~K}_{660}$ & $172,110,181$ & 1 eqv+NPK+St \\
\hline
\end{tabular}

Legends: $1 \mathrm{FYM}(5)=35 \mathrm{Mg} \mathrm{ha}^{-1}$ farmyard manure in 5 years, distributed in the first and third year; leqv = mineral NPK equivalent to $35 \mathrm{Mg} \mathrm{ha}^{-1} \mathrm{FYM}$ in 5 years, $\mathrm{N}$ distributed yearly, PK in the first and third year; $\mathrm{Straw}(\mathrm{St})=$ wheat straw and maize stalk ploughed in 
Model pot experiment was set up with maize (Zea mays L.) as test plant in the closed section of a greenhouse in 2008, 2009 and 2010. Large pots $(40 \times 40 \mathrm{~cm})$ were filled with $45 \mathrm{~kg}$ (calculated as absolute dry) soil taken from the field plots of the above selected treatments. Gas traps of $1.8 \mathrm{dm}^{3}$ volume were laid at a depth of $20 \mathrm{~cm}$ into the soil. Four plants per pots were grown until full maturity. The greenhouse experiment was set up with three replications in a randomized block design. The plants were watered, maintaining the optimal water supplying capacity of the test soils during the whole experimental period. Gas samples were taken each time at about 8 a.m. by a gas-tight syringe and injected into evacuated Exetainer tubes (Labco Limited, UK). In 2008, 2009 and 2010 the soil air sampling was performed 9, 10 and 11 times, respectively, during the vegetation season. From these data, the dynamics and cumulative values of $\mathrm{CO}_{2}$ and $\mathrm{N}_{2} \mathrm{O}$ production was determined and evaluated statistically. The yield response of the selected treatments both on field and mesocosm level was evaluated and published [18, 19].

\section{Soil column experiment}

Undisturbed soil columns have been prepared as it was described by Szili-Kovács et al [20] from the nearby long-term experimental field of Pannon Agricultural University, Keszthely, Hungary in the spring of 2008 year. After consolidation, they were carefully transported the columns to experimental field in Orbottyán and placed them outdoor in a secured pit. The soil type was brown forest soil (Eutric cambisol), and was not cultivated before sampling. The humus content was $1.7 \%$, the $\mathrm{pH}_{\mathrm{KCl}}$ was 5.4. The height and diameter of the prepared columns were 0.9 and $0.4 \mathrm{~m}$, respectively. At 20, 40 and $60 \mathrm{~cm}$ depth gas permeable silicon tube $(320 \mathrm{~mm}$ in length; $16 \mathrm{~mm}$ in outside diameter; $12 \mathrm{~mm}$ in inner diameter) gas traps were built in perpendicularly and their ending was closed by a septum for gas sampling [20]. In 2009, 2010 and 2011 the soil columns had different treatments: 1) control with no plants; 2) mineral fertilised with no plants; 3 ) no fertiliser and maize plants; 4) mineral fertilised and maize plants; 5) manure and maize plants; 6) mineral fertilised plus manure and maize plants. The mineral nitrogen fertiliser was added in spring of each year while farmyard manure was added only in 2008 and 2010 years at the rate of corresponding to the mesocosm experiment treatments. Fertilisers were raked into the top of columns. Maize was seeded in each column except treatments 1 and 2 at the beginning of May. Only one plant per column was left to grow up. The columns were not irrigated in 2010 years, but water was added in 2009 and 2011 year altogether 261 and $207 \mathrm{~mm}$, respectively, from July to September. Soil air was sampled 10, 13 and 20 times during the vegetation season in 2009, 2010 and 2011, respectively, at the same time in the morning. From these data, the dynamics and cumulative values of $\mathrm{CO}_{2}$ and $\mathrm{N}_{2} \mathrm{O}$ production were determined and evaluated statistically. In addition, in 2011 soil surface $\mathrm{CO}_{2}$ flux changes were followed by gas sampling from closed-chambers inserted into the top of each column at zero and at 30 minutes after closure. Gas samples were taken by a Hamilton gas-tight syringe $\left(10 \mathrm{~cm}^{3}\right.$, side-port syringe) and injected into evacuated Exetainer tubes (Labco Limited, UK). The tubes were transported to the laboratory on the day of sampling and measured within one day. Soil was sampled 6 and 7 times during the vegetation seasons in 2010 and 2011 respectively from the $0-20 \mathrm{~cm}$ layer by a corer. Soil samples were also taken to measure active microbial biomass by substrate-induced respiration (SIR) and microbial activity based on fluorescein-diacetate hydrolysing activity (FDA). The results of these latter experiments are published [21, 22]. 


\section{Microcosm experiments}

The microcosm experiments were conducted in $1.2 \mathrm{dm}^{3}$ glass vessels covered by silicone septa. $200 \mathrm{~g}$ homogenized $(<2 \mathrm{~mm})$ soil from the control plot of the field experiment was placed onto the bottom of the vessels, and then it was treated by adding and mixing of organic manure (farmyard or plant residue) and inorganic $\mathrm{N}$-source $\left(\mathrm{KNO}_{3}\right)$ singly or in combination. Then, the soil moisture was set up to $90 \%$ of the water holding capacity and vessels were incubated in a laboratory thermostat at two different constant temperatures $\left(15\right.$ and $37^{\circ} \mathrm{C}$ ) during 30-70 days. Emission of $\mathrm{N}_{2} \mathrm{O}, \mathrm{NO}$ and $\mathrm{CO}_{2}$ gases from homogenized soil was detected in $0.250 \mathrm{~cm}^{3}$ headspace gas samples taken with 1-3 day frequency by gas tight Hamilton syringes throw the covering septa.

\section{Results and discussion}

The dynamics of $\mathrm{CO}_{2}$ and $\mathrm{N}_{2} \mathrm{O}$ formation in gas traps of mesocosm pots during 2010 and in gas traps of undisturbed soil columns during 2011 are presented on Figures 1 and 2, respectively.

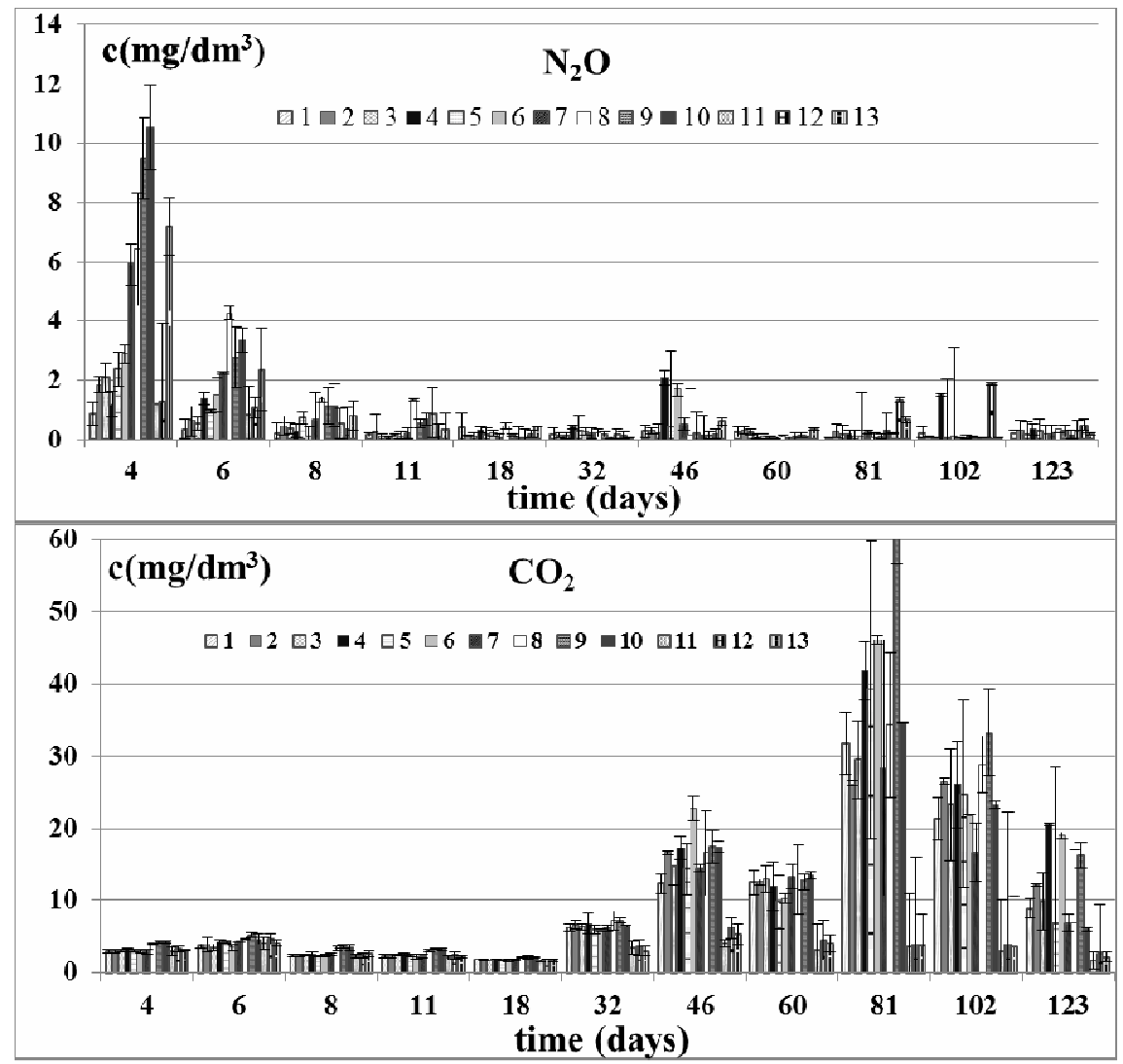

Fig. 1. Change of $\mathrm{CO}_{2}$ concentration measured in $\mathrm{mg} / \mathrm{dm}^{3}$ units and the $\mathrm{N}_{2} \mathrm{O}$ concentration measured in $\mu \mathrm{g} / \mathrm{dm}^{3}$ units, in soil air samples taken from gas traps of pot experiment during the vegetation period in 2010. Meaning of symbols of treatments 1-13 is given in Tables 1 and 2 
As it can be observed on Figures 1 and 2, the $\mathrm{CO}_{2}$ concentration in the gas traps in both experimental systems has changed similarly during the vegetation period, ie after a stagnation period, one or two maximums decreased to the initial level until the harvest time. These changes have shown a good correlation with the mean daily temperature [20, 23].

A)

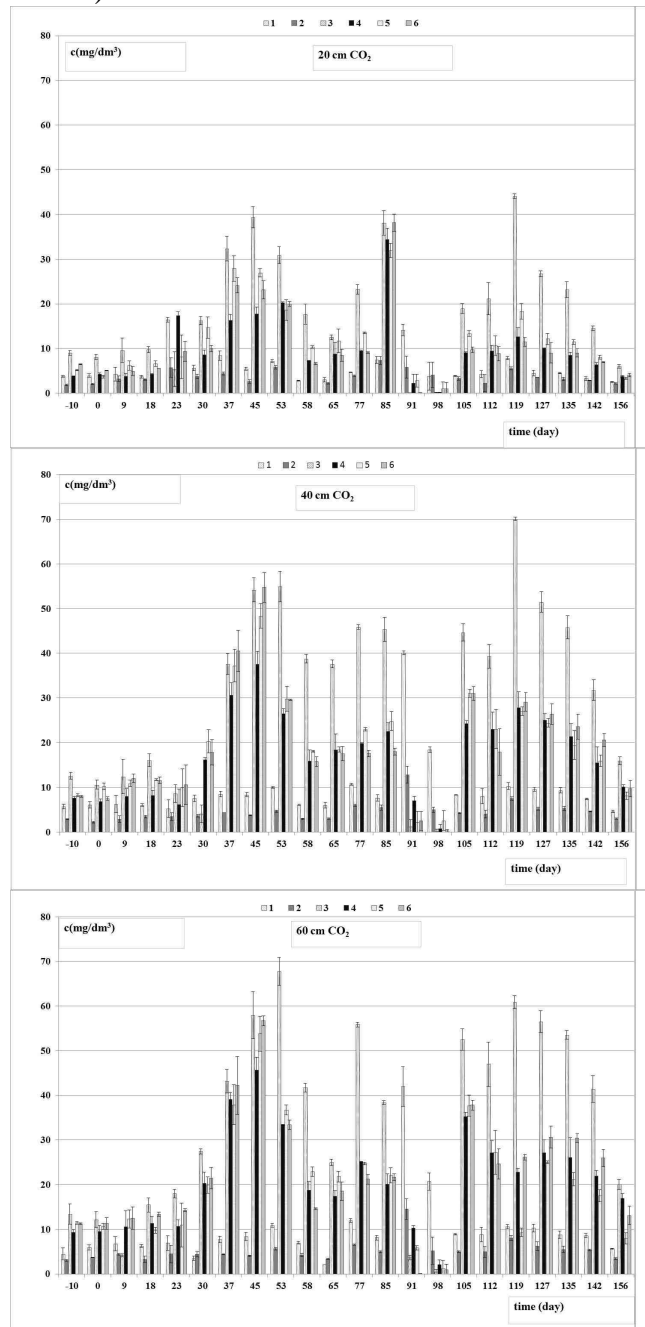

B)

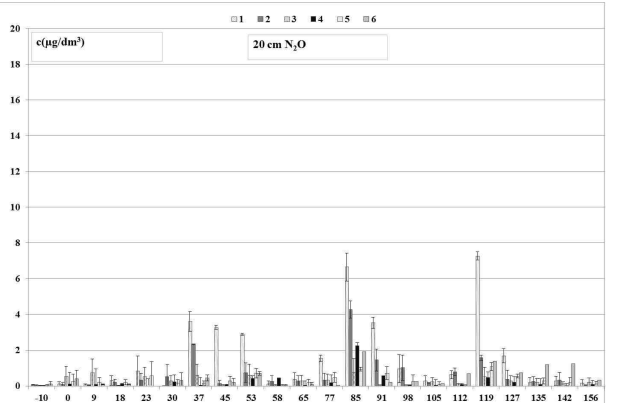

time (day)

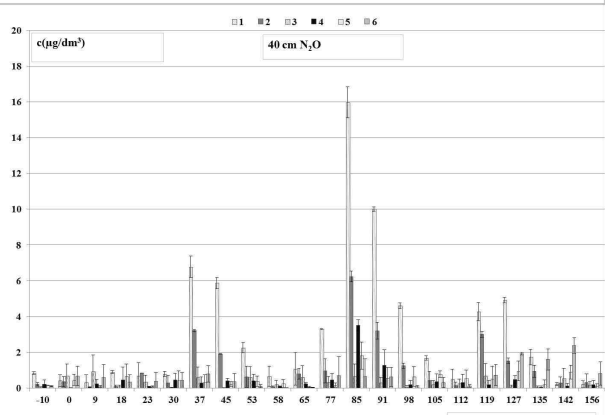
time (day)

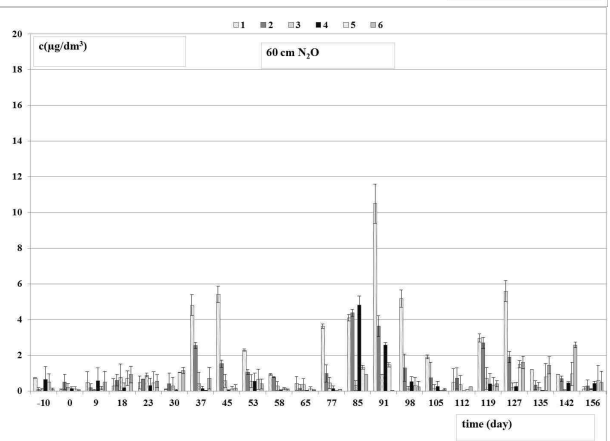

Fig. 2. Change of $\mathrm{CO}_{2}$ concentration measured in $\mathrm{mg} / \mathrm{dm}^{3}$ units (A) and the $\mathrm{N}_{2} \mathrm{O}$ concentration measured in $\mu \mathrm{g} / \mathrm{dm}^{3}$ units (B), in soil air samples taken from gas traps built in the soil columns at 20,40 and $60 \mathrm{~cm}$ depth during the vegetation period in 2011. Symbols of fertiliser treatments 1-6 is given in Section Materials and methods 
The dynamics of $\mathrm{N}_{2} \mathrm{O}$ formation did not show such unambiguous tendency: in the soil columns during the vegetation period two or three outlying maxima can be observed which are more or less synchronous with the maxima of $\mathrm{CO}_{2}$ production, while in the mesocosm pots only in the initial period (until the 6th day) could be detected a peak. This kind of shift in dynamics of $\mathrm{CO}_{2}$ and $\mathrm{N}_{2} \mathrm{O}$ formation was observed in our earlier [23] and recent microcosm experiments as it is presented on Figure 3.

Table 2

Cumulative values of $\mathrm{CO}_{2}$ production given in $\mathrm{mg}$ units measured during the vegetation period in the gas traps built into $20 \mathrm{~cm}$ depth of the soil of the mesocosm pot experiment. The meaning of treatments 1-10 are give in Table 1. In 2008 the treatments 1, 4 and 7 were performed with gas traps positioned on the soil surface as given in the 11, 12 and 13 column respectively. In 2010 the treatments 1, 4 and 7 were performed without plant growing as given in the 11,12 and 13 column respectively

\begin{tabular}{|c|c|c|c|c|c|c|c|c|c|c|c|c|c|c|}
\hline $\begin{array}{c}\text { Treat- } \\
\text { ments }\end{array}$ & $\mathbf{1}$ & $\mathbf{2}$ & $\mathbf{3}$ & $\mathbf{4}$ & $\mathbf{5}$ & $\mathbf{6}$ & $\mathbf{7}$ & $\mathbf{8}$ & $\mathbf{9}$ & $\mathbf{1 0}$ & $\mathbf{1 1}$ & $\mathbf{1 2}$ & $\mathbf{1 3}$ & $\begin{array}{c}\text { LSD } \\
{[\mathbf{5 \%}]}\end{array}$ \\
\hline 2008 & 220.8 & 259.8 & 241.2 & 270.2 & 227.9 & 273.8 & 269.4 & 278.9 & 300.0 & 280.2 & 178.0 & 168.8 & 178.1 & 91.9 \\
\hline 2009 & 300.9 & 310.7 & 340.5 & 329.6 & 276.9 & 326.7 & 261.9 & 306.2 & 374.9 & 334.7 & & & & 60.8 \\
\hline 2010 & 189.0 & 205.0 & 197.8 & 250.3 & 206.7 & 249.5 & 178.8 & 164.8 & 298.3 & 214.1 & 57.2 & 69.5 & 64.0 & 77.8 \\
\hline
\end{tabular}

Significant differences detected in the years:

$\begin{array}{lll}2008 & 2009 & 2010 \\ 4>11,12,13 & 4>7 & 2>11,12,13 \\ 5<9 & 5<3,9 & 3<9 \\ 6>11,12,13 & 6>7 & 3>11,12,13 \\ 7>11,12,13 & 7<3,4,6,9,10 & 4>8 \\ 8>11,12,13 & 8<9 & 4>11,12,13 \\ 9>1,5,11,12,13 & 9>1,2,5,7,8 & 5<9 \\ 10>11,12,13 & 10>7 & 5>11,12,13 \\ 11<2,4,6,7,8,9,10 & & 6>8 \\ 12<2,3,4,6,7,8,9,10 & & 6>11,12,13 \\ 13<2,4,6,7,8,9,10 & & 7<9 \\ & & 7>11,12,13 \\ & & 8<4,6,9 \\ & & 8>11,12,13 \\ & & 9>1,2,3,5,7,8,10,11,12,13 \\ & & 10<9 \\ & & 10>11,12,13 \\ & & 11<1,2,3,4,5,6,7,8,9,10 \\ & & 12<1,2,3,4,5,6,7,8,9,10\end{array}$

Cumulative values of $\mathrm{CO}_{2}$ and $\mathrm{N}_{2} \mathrm{O}$ production during the vegetation period given in $\mathrm{mg}$ units measured in the gas traps built into $20 \mathrm{~cm}$ depth of the soil of the mesocosm pot experiment in 2008, 2009 and 2010 are presented in Tables 2 and 3, respectively. Cumulative values of $\mathrm{CO}_{2}$ and $\mathrm{N}_{2} \mathrm{O}$ production during the vegetation period given in $\mathrm{mg}$ units measured in the gas traps built into 20,40 and $60 \mathrm{~cm}$ depth of the undisturbed soil columns in 2009, 2010 and 2011 are presented in Table 4 and in Table 5, respectively.

In Table 2, data for year 2008 show significant increase of $\mathrm{CO}_{2}$ production between the gas traps on the surface and traps at $20 \mathrm{~cm}$ depth, while for $\mathrm{N}_{2} \mathrm{O}$ production such tendency cannot be verified. According to Figure 2 and Tables 4 and 5 it can concluded that the depth profile of $\mathrm{CO}_{2}$ production in soil columns shows an increasing tendency, the increase between 20 and $40 \mathrm{~cm}$ is significant, while between 40 and $60 \mathrm{~cm}$ the increase is partly significant. Similar tendency can be observed for depth profile of $\mathrm{N}_{2} \mathrm{O}$ production in the soil 
columns, but due to the higher uncertainty of $\mathrm{N}_{2} \mathrm{O}$ determinations less significant relation was obtained. On Figure 4 surface $\mathrm{CO}_{2}$ flux from soil columns during the vegetation season from $13^{\text {th }}$ April till $1^{\text {st }}$ till 1 st September $(0=$ control; NPK $=$ NPK treatment; $M=$ presence of maize plant; FYM = farmyard manure) is presented. The $\mathrm{CO}_{2}$ emission values calculated from these data show a good agreement with data measured for similar condition by Galbally et al [14].

On the basis of the significant differences between treatments as it was listed in Tables 2-4 and 5 the following conclusion can be made: the presence of plants in unfertilised treatments increased the $\mathrm{CO}_{2}$ and $\mathrm{N}_{2} \mathrm{O}$ production both in the pots and in the soil columns. On the effect of manure or fertiliser application, the production of both gases decreased in the soil columns. The decrease is less in the presence of plants and organic manure, as in the case of mineral fertilisers, too. On the contrary, in the mesocosm pots the $\mathrm{CO}_{2}$ and the $\mathrm{N}_{2} \mathrm{O}$ production was increased when manuring or mineral fertilisers were applied. The order has followed the grain yield increasing effects of the plant nutrients treatments: (manure) $<($ mineral fertiliser $)<($ manure $)+($ mineral fertiliser $)[23]$.

Cumulative values of $\mathrm{N}_{2} \mathrm{O}$ production given in $\mathrm{ng}$ units measured during the vegetation period in the gas traps built into $20 \mathrm{~cm}$ depth of the soil of the mesocosm pot experiment. The meaning of treatments 1-10 are given in Table 1. In 2008 the treatments 1, 4 and 7 were performed with gas traps positioned on the soil surface as given in the 11,12 and 13 column respectively. In 2010 the treatments 1, 4 and 7 were performed without plant growing as given in the 11,12 and 13 column respectively

\begin{tabular}{|c|c|c|c|c|c|c|c|c|c|c|c|c|c|c|}
\hline $\begin{array}{l}\text { Treat- } \\
\text { ments }\end{array}$ & $\mathbf{1}$ & $\mathbf{2}$ & $\mathbf{3}$ & $\mathbf{4}$ & $\mathbf{5}$ & $\mathbf{6}$ & $\mathbf{7}$ & $\mathbf{8}$ & $\mathbf{9}$ & $\mathbf{1 0}$ & $\mathbf{1 1}$ & $\mathbf{1 2}$ & $\mathbf{1 3}$ & $\begin{array}{c}\text { LSD } \\
\text { [5\%] }\end{array}$ \\
\hline 2008 & 4330 & 4328 & 4869 & 4761 & 4767 & 5164 & 6681 & 5078 & 4359 & 4060 & 5337 & 6518 & 5079 & 2817 \\
\hline 2009 & 5169 & 4949 & 4298 & 4066 & 4912 & 4417 & 5851 & 4239 & 3901 & 5036 & & & & 2625 \\
\hline 2010 & 5700 & 7577 & 7801 & 14337 & 10248 & 13346 & 18734 & 26815 & 27054 & 30103 & 7730 & 12842 & 23570 & 5617 \\
\hline
\end{tabular}

Significant differences were detected only in 2010 as it follows:

$1<4,6,7,8,9,10,12,13$

$2<4,6,7,8,9,10,13$

$3<4,7,8,9,10,13$

$4>1,2,3,11$

$4<8,9,10,13$

$5<7,8,9,10,13$

$6>1,2$

$6<8,9,10,13$

$7>1,2,3,5,11,12$

$7<8,9,10$

$8>1,2,3,4,5,6,7,11,12$

$9>1,2,3,4,5,6,7,11,12$

$10>1,2,3,4,5,6,7,11,12,13$

$11<4,7,8,9,10,13$

$12>1$

$12<7,8,9,10,13$

$13>2,3,4,5,6,11,12$

$13<10$ 


\section{$90 \% \mathrm{WHC}$}

Incubation temperature: $37^{\circ} \mathrm{C}$
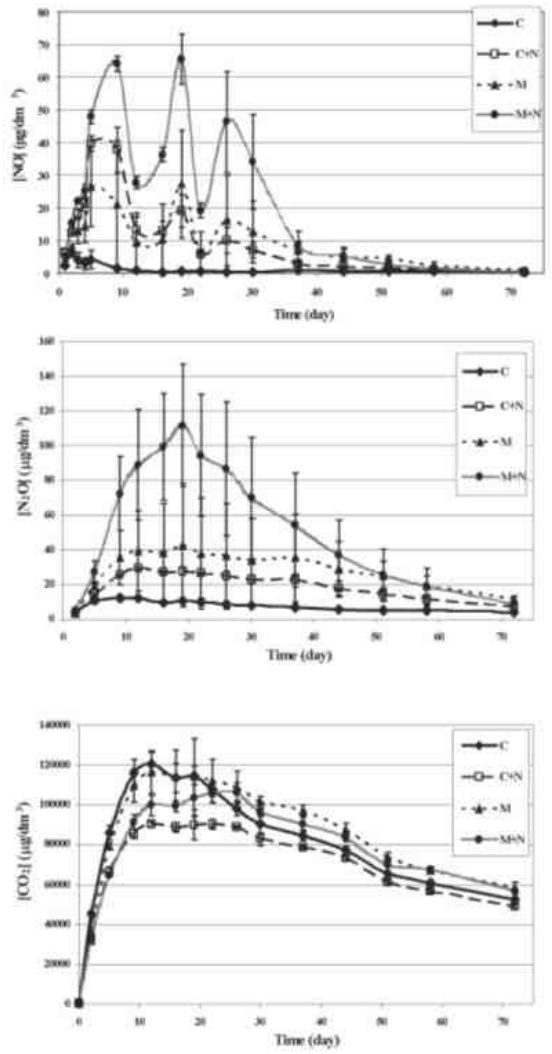

\section{Incubation temperature: $15^{\circ} \mathrm{C}$}
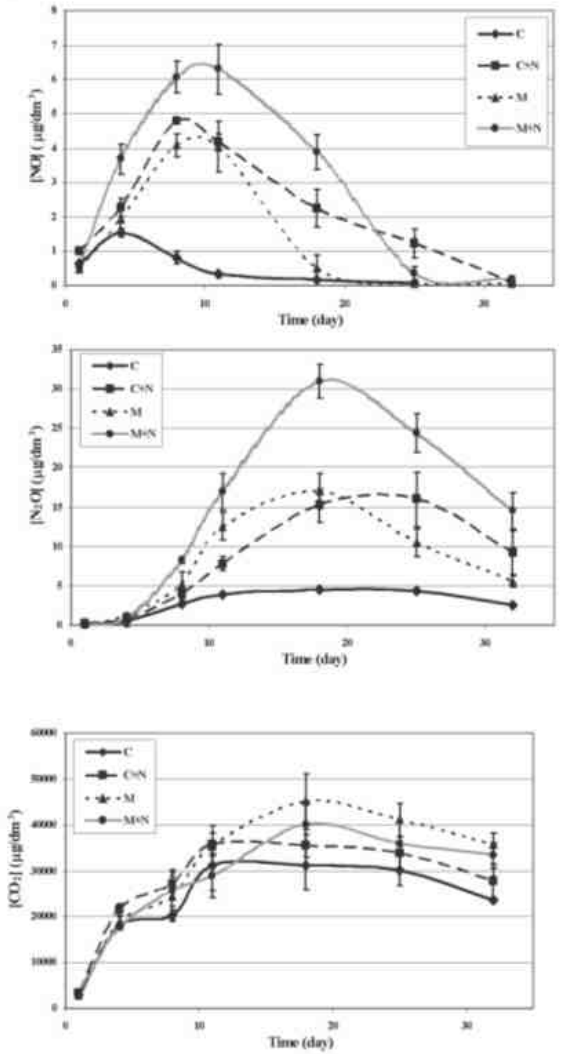

Fig. 3. Change of $\mathrm{NO}, \mathrm{N}_{2} \mathrm{O}$ and $\mathrm{CO}_{2}$ concentration in the headspace of microcosm vessels in the function of incubation time

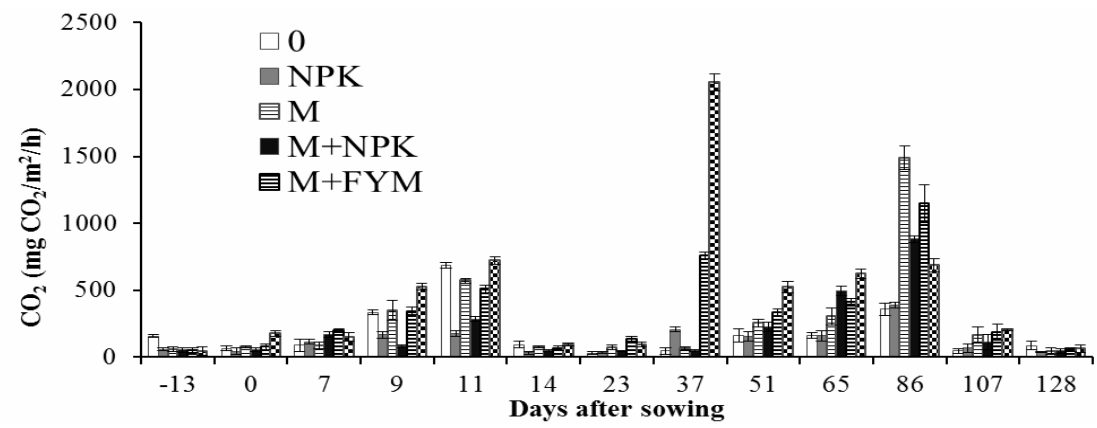

Fig. 4. Surface $\mathrm{CO}_{2}$ flux from soil columns during the 2011 vegetation season from $13^{\text {th }}$ April till $1^{\text {st }}$ September $(0=$ control; NPK $=$ NPK treatment; $\mathrm{M}=$ presence of maize plant; FYM = farmyard manure) 
Table 4

Cumulative values of $\mathrm{CO}_{2}$ production given in $\mathrm{mg}$ units measured during the vegetation period in the gas traps built into the undisturbed soil columns at depth of 20,40 and $60 \mathrm{~cm}$. The meaning of treatments 1-6 are given in the section of Soil columns-Materials and methods. The symbol * means that the value is significantly higher than the value measured at $20 \mathrm{~cm}$ depth. The symbol + means that the value is significantly higher than the value measured at $40 \mathrm{~cm}$ depth

\begin{tabular}{|c|c|c|c|c|}
\hline Treatments & Depth [cm] & 2009 & 2010 & 2011 \\
\hline \multirow{3}{*}{ 然 } & 20 & 6.42 & 3.77 & 2.20 \\
\hline & 40 & $* 14.94$ & $* 7.02$ & $* 4.83$ \\
\hline & 60 & $* 15.79$ & $* 7.45$ & $+* 5.20$ \\
\hline \multirow{3}{*}{2} & 20 & 4.82 & 2.52 & 1.59 \\
\hline & 40 & $* 7.34$ & $* 3.91$ & $* 2.21$ \\
\hline & 60 & $+* 8.99$ & $+* 4.94$ & $+* 2.51$ \\
\hline \multirow{3}{*}{3} & 20 & 10.82 & 11.59 & 7.79 \\
\hline & 40 & $* 17.58$ & $* 20.27$ & $* 14.09$ \\
\hline & 60 & $* 18.05$ & $+* 22.17$ & $+* 15.48$ \\
\hline \multirow{3}{*}{4} & 20 & 4.58 & 5.47 & 3.83 \\
\hline & 40 & $* 7.22$ & $* 10.95$ & $* 7.08$ \\
\hline & 60 & $+* 8.56$ & $+* 13.30$ & $+* 8.33$ \\
\hline \multirow{3}{*}{5} & 20 & 7.00 & 8.43 & 4.57 \\
\hline & 40 & $* 9.35$ & $* 15.39$ & $* 7.26$ \\
\hline & 60 & $+* 10.38$ & $* 15.62$ & $* 7.12$ \\
\hline \multirow{4}{*}{6} & 20 & 4.96 & 5.49 & 3.87 \\
\hline & 40 & $* 7.88$ & $* 10.89$ & $* 7.07$ \\
\hline & 60 & $+* 9.99$ & $+* 13.26$ & $+* 8.38$ \\
\hline & & $\operatorname{LSD}_{[5 \%]}=0.93$ & $\operatorname{LSD}_{[5 \%]}=0.69$ & $\operatorname{LSD}_{[5 \%]}=0.33$ \\
\hline
\end{tabular}

Significant differences detected between the treatments at $20 \mathrm{~cm}$ depth:

2009: $1>2,4,6 \quad 2<3,5 \quad 3>4,5,6 \quad 4<5 \quad 5>6$

2010: $1>21<3,4,5,6 \quad 2<3,4,5,6 \quad 3>4,5,6 \quad 4<5 \quad 5>6$

2011: $1>2 \quad 1<3,4,5,6 \quad 2<3,4,5,6 \quad 3>4,5,6 \quad 4<5 \quad 5>6$

Significant differences detected between the treatments at $40 \mathrm{~cm}$ depth:

2009: $1>2,4,5,6 \quad 1<3 \quad 2<3,5 \quad 3>4,5,6 \quad 4<5 \quad 5>6$

2010: $1>2 \quad 1<3,4,5,6 \quad 2<3,4,5,6 \quad 3>4,5,6 \quad 4<5 \quad 5>6$

2011: $1>2 \quad 1<3,4,5,6 \quad 2<3,4,5,6 \quad 3>4,5,6$

Significant differences detected between the treatments at $60 \mathrm{~cm}$ depth:

2009: $1<3 \quad 1>2,4,5,6 \quad 2<3,5,6 \quad 3>4,5,6 \quad 4<5,6 \quad 5>6$

2010: $1>2 \quad 1<3,4,5,6 \quad 2<3,4,5,6 \quad 3>4,5,6 \quad 4<5 \quad 5>6$

2011: $1>2 \quad 1<3,4,5,6 \quad 2<3,4,5,6 \quad 3>4,5,6 \quad 4>5 \quad 5<6$

Table 5

Cumulative values of $\mathrm{N}_{2} \mathrm{O}$ production given in ng units measured during the vegetation period in the gas traps built into the undisturbed soil columns at depth of 20,40 and $60 \mathrm{~cm}$. The meaning of treatments 1-6 are given in the section of Soil columns-Materials and methods. The symbol * means that the value is significantly higher than the value measured at $20 \mathrm{~cm}$ depth. The symbol + means that the value is significantly higher than the value measured at $40 \mathrm{~cm}$ depth. The symbol - means that the value is significantly less than the value measured at $40 \mathrm{~cm}$ depth

\begin{tabular}{|c|c|c|c|c|}
\hline Treatment & Depth [cm] & $\mathbf{2 0 0 9}$ & $\mathbf{2 0 1 0}$ & $\mathbf{2 0 1 1}$ \\
\hline \multirow{3}{*}{1} & 20 & 2802 & 948 & 836 \\
\cline { 2 - 5 } & 40 & $* 4154$ & $* 2096$ & $* 1681$ \\
\cline { 2 - 5 } & 60 & $* 4260$ & $* 2167$ & $-* 1241$ \\
\hline \multirow{3}{*}{2} & 20 & 648 & 301 & 365 \\
\cline { 2 - 5 } & 40 & 866 & 371 & $* 636$ \\
\cline { 2 - 5 } & 60 & $+* 1220$ & $* 489$ & $* 582$ \\
\hline
\end{tabular}




\begin{tabular}{|c|c|c|c|c|}
\hline Treatment & Depth [cm] & $\mathbf{2 0 0 9}$ & $\mathbf{2 0 1 0}$ & $\mathbf{2 0 1 1}$ \\
\hline \multirow{3}{*}{3} & 20 & 257 & 158 & 96 \\
\cline { 2 - 5 } & 40 & 295 & $* 371$ & 115 \\
\cline { 2 - 5 } & 60 & 555 & $* 399$ & 122 \\
\hline \multirow{4}{*}{4} & 20 & 131 & 73 & 146 \\
\cline { 2 - 5 } & 40 & 132 & 91 & $* 243$ \\
\cline { 2 - 5 } & 60 & 225 & $* 236$ & 162 \\
\hline \multirow{3}{*}{5} & 20 & 366 & 157 & $* 247$ \\
\cline { 2 - 5 } & 40 & 517 & 190 & 240 \\
\hline \multirow{3}{*}{6} & 60 & 474 & 270 & 283 \\
\cline { 2 - 5 } & 20 & 88 & 185 & -+258 \\
\cline { 2 - 5 } & 40 & 374 & 205 & LSD $_{[5 \%]}=80$ \\
\hline
\end{tabular}

Significant differences detected between the treatments at $20 \mathrm{~cm}$ depth:

2009: $1>2,3,4,5,6 \quad 2>3,4,5,6$

2010: $1>2,3,4,5,6 \quad 2>4,5 \quad 4>6 \quad 5>6$

2011: $1>2,3,4,5,6 \quad 2>3,4,5,6 \quad 3>6 \quad 4>6 \quad 5>6$

Significant differences detected between the treatments at $40 \mathrm{~cm}$ depth:

2009: $1>2,3,4,5,6 \quad 2>3,4,5,6 \quad 4<5 \quad 5>6$

2010: $1>2,3,4,5,6 \quad 2>4,5,6 \quad 3>4,5,6$

2011: $1>2,3,4,5,6 \quad 2>3,4,5,6 \quad 3<4,5,6 \quad 4<6 \quad 5<6$

Significant differences detected between the treatments at $60 \mathrm{~cm}$ depth:

2009: $1>2,3,4,5,6 \quad 2>3,4,5,6 \quad 3>4$

2010: $1>2,3,4,5,6 \quad 2>4,5,6$

2011: $1>2,3,4,5,6 \quad 2>3,4,5,6 \quad 3<4,5,6$

\section{Conclusions}

On the basis of the presented data it can be concluded that the conditions of formation and emission of $\mathrm{CO}_{2}$ and $\mathrm{N}_{2} \mathrm{O}$ gases are different in the uncultivated and cultivated agricultural soils and these processes are significantly influenced by the presence of plants and microbiological activity of the soil. Therefore, real estimation of GHG emissions from agricultural soils can be obtained in such joint experimental systems as it was presented in this paper.

\section{Acknowledgements}

The National Scientific Research Fund supported this work (OTKA consortium: K 72926, K 73326, K 73768).

\section{References}

[1] IPCC (Intergovernmental Panel on Climate Change). http://www.ipcc.ch/index.htm.

[2] GEIA (Global Emissions Initiative). http://www.geiacenter.org/.

[3] EDGAR (Emissions Database For Global Atmospheric Research). http://ies.jrc.ec.europa.eu/dataportals.html/\#dp25.

[4] Rowlings D, Grace P, Kiese R, Scheer C. Quantifying $\mathrm{N}_{2} \mathrm{O}$ and $\mathrm{CO}_{2}$ emissions from a subtropical pasture. $19^{\text {th }}$ World Congress of Soil Science, Soil Solutions for a Changing World. 1-6 August 2010. Brisbane, Australia. Published on DVD.

[5] Yang ZP, Turner DA, Zhang JJ, Wang YL, Chen MC, Zhang Q, Denmead OT, Chen D, Freney JR. Soil Res. 2011;49(5):462-469. DOI: 10.1071/Sr11107.

[6] Akimoto F, Matsunami A, Kamata Y, Kodama I, Kitagawa K, Arai N, et al. Energy. 2005;30:299-311. 
[7] Mørkved PT, Dörsch P, Henriksen TM, Bakken LR. Soil Biol and Biochem. 2006;38:3411-3420.

[8] Ruser R, Flessa H, Russow R, Schmidt G, Buegger F, Munch JC. Soil Biol and Biochem. 2006;38:263-274.

[9] Lokupitiya E, Paustian K. J Environ Qual. 2005;35:1413-1417.

[10] Ganzeveld L. Soil-biogenic NOx emissions: global scale inventories. GEA Review 02/28/05. http://www.geiacenter.org/

[11] Conrad R. Soil microbial communities and global climate change - methanotrophic and methanogenic communities as paradigms. In: Modern Soil Microbiology. Second Edition. (VanElsas JD, Jansson J, Trevors, JT, editors.). Boca Raton (FL): CRC Press; 2007;263-282.

[12] Jungkunst HF, Bargsten A, Timme M, Glatzel S. Journal of Plant Nutrition and Soil Science. 2012;175(5):739-749. DOI: 10.1002/jpln.201100412.

[13] Ganzeveld L, Lelicveld J, Dentener FJ, Krol MC, Bouwman AF, Roelofs GJ. J Geophys Res. 2002;107:1029-1289.

[14] Galbally IE, Meyer CP, Wang YP, Kirstine WK, Smith CJ, Weeks IA. Measurements of soil-atmosphere exchange of $\mathrm{CH}_{4}, \mathrm{CO}, \mathrm{N}_{2} \mathrm{O}$ and $\mathrm{NOx}$ in the semi-arid mallee system in Southeastern Australia. Centre for Australian Weather and Climate Research. Technical Report. 2008;002.1-62.

[15] Parton WJ, Holland EA, Del Grosso SJ, Hartman MD, Martin RE, Mosier AR, Ojima DS, Schimel DS. Journal of Geophysical Research: Atmospheres. 2001;106(D15):17403-17419. DOI: 10.1029/2001JD900101.

[16] Olander L, Wollenberg E, Tubiello F, Herold M. Environ Res Lett. 2013;(8):011002.1-7. DOI: $10.1088 / 1748-9326 / 8 / 1 / 011002$.

[17] Li D. PLoS ONE. 2013;8(3):e59360. DOI: 10.1371/journal.pone.0059360.

[18] Hoffmann S, Berecz K, Hoffmann B, Bankó L. Cereal Res Commun Suppl. 2008;36(1):1631-1634.

[19] Hoffmann S, Lepossa A, Balint A, Molnar E, Heltai G. Comparative study of some agronomic and environmental effects of mineral and organic fertilisation with maize (Zea Mays L.) in field and model pot experiments, 19. Istro Conference, (Montevideo) Abstract, 2012.

[20] Szili-Kovács T, Bálint Á, Kampfl Gy, Kristóf K, Heltai Gy, Hoffmann S, Lukács A, Anton A. Agrokemia es Talajtan. 2009;58:359-368.

[21] Szili-Kovács T, Molnár E, Villányi I, Bálint Á, Heltai Gy, Anton A. Acta Microbiol Et Immunol Hungarica. 2011;58:224-225.

[22] Szili-Kovács T, Molnár E, Villányi I, Knáb M, Bálint Á, Heltai Gy, Anton A. Plant Soil and Environ. (Submitted for publication).

[23] Kampfl G, Kristof K, Algaidi AA, Hamuda HEAFB, Heltai G. Microchem J. 2007;85(1):31-38.

\title{
UDZIAŁ PRODUKCJI ROLNEJ W EMISJI GAZÓW CIEPLARNIANYCH
}

\begin{abstract}
Abstrakt: Światowa produkcja rolnicza przyczynia się znacząco do zwiększenia stężenia gazów cieplarnianych $\left(\mathrm{CO}_{2}, \mathrm{~N}_{2} \mathrm{O}, \mathrm{CH}_{4}\right)$ w atmosferze, jednak dane szacunkowe dotyczące tych emisji pochodzących z gleby różnią się istotnie. W szczególności dotyczy to tlenków azotu, których emisja wykazuje dużą zmienność czasową i przestrzenną, podczas gdy ich tworzenie w procesach mikrobiologicznych jest silnie uzależnione od biogeochemicznych i fizycznych właściwości gleby (np. gatunków mikroorganizmów, struktury gleby, wód glebowych, $\mathrm{pH}$, potencjałów redoks i substancji odżywczych) oraz wpływu zarządzania gruntami poprzez stosowanie nawozów naturalnych i sztucznych, rodzaju uprawy, nawadniania, sadzenia i zbiorów. Różne systemy monitorowania i modele inwentaryzacyjne zostały opracowane głównie z punktu widzenia chemii atmosferycznej. Istnieje niewiele całościowych danych dotyczących emisji gazów cieplarnianych i ich produkcji w glebach rolniczych w warunkach ekologicznych Europy Środkowej. Przedstawiono nowe wyniki prac realizowanych w ramach projektu dotyczącego opracowania systemu doświadczalnego, odpowiedniego do badania relacji między produkcją i emisją gazów cieplarnianych a nawożeniem roślin w węgierskich warunkach ekologicznych. Eksperyment oparty był na długotrwałym doświadczeniu polowym. W doświadczeniach wykorzystano gleby pochodzące $\mathrm{z}$ różnych działek. W okresie wegetacyjnym produkcja $\mathrm{CO}_{2} \mathrm{i} \mathrm{N}_{2} \mathrm{O}$ była śledzona za pomocą pułapek gazowych umieszczonych na głębokości $20 \mathrm{~cm}$. W celu wyjaśnienia wpływu procesów mikrobiologicznych i środowiskowych na produkcję gazu w glebie wykonano szereg mikroskalowych doświadczeń laboratoryjnych. Stężenia $\mathrm{CO}_{2}$ i $\mathrm{N}_{2} \mathrm{O}$ oznaczano metodą chromatografii gazowej. Stężenia $\mathrm{NO}_{\mathrm{x}} \mathrm{w}$ górnych obszarach badanych mikrosystemów oznaczano metodą chemiluminescencji. W mezoskali i w kolumnach glebowych eksperymenty
\end{abstract}


dotyczące wpływu metod dożywiania roślin i czynników środowiskowych z powodzeniem wyjaśniały dynamikę zmian sezonowych i produkcję $\mathrm{CO}_{2}$ i $\mathrm{N}_{2} \mathrm{O}$ w profilu głębokościowym. Opracowana baza danych jest odpowiednia do oszacowania emisji $\mathrm{CO}_{2}$ i $\mathrm{N}_{2} \mathrm{O}$ z gleb rolnych.

Słowa kluczowe: gazy cieplarniane, długoterminowy eksperyment pole - mezoskala - kolumna glebowa mikroskala 